\title{
ERRATUM
}

\section{Erratum to: Secukinumab: A New Treatment Option for Psoriatic Arthritis}

Philip Mease $\cdot$ Iain B. McInnes

Published online: July 25, 2016

(C) The Author(s) 2016. This article is published with open access at Springerlink.com

Erratum to: Rheumatol Ther (2016) 3:5-29

DOI 10.1007/s40744-016-0031-5

In the original version, the second paragraph (last sentence) of the section "Efficacy of Secukinumab in Patient Subgroups" under heading FUTURE 1 AND FUTURE 2, a value is incorrect. The correct sentence should read as:

The Week 52 observed data were $62.1 \%$ for secukinumab $300 \mathrm{mg}, 48.3 \%$ for secukinumab $150 \mathrm{mg}$, and $63.2 \%$ for secukinumab $75 \mathrm{mg}$ (Fig. 12b).

\section{OPEN ACCESS}

This article is distributed under the terms of the Creative Commons AttributionNonCommercial 4.0 International License (http://creativecommons.org/licenses/by-nc/4. $0 /$ ), which permits any noncommercial use, distribution, and reproduction in any medium, provided you give appropriate credit to the original author(s) and the source, provide a link to the Creative Commons license, and indicate if changes were made.

The online version of the original article can be found under doi:10.1007/s40744-016-0031-5.

P. Mease $(\varangle)$

Swedish Medical Center and the University of

Washington, Seattle, WA, USA

e-mail: pmease@philipmease.com

I. B. McInnes

Institute of Infection, Immunity and Inflammation,

University of Glasgow, Glasgow, UK 